\title{
The Role of Ozone Carried by Liposomes in the Therapy of Infectious and Skin-Regenerating Ocular Surface
}

\author{
Anna Cutarelli', Gianpaolo Carlini' ${ }^{2}$, Federica Sarno ${ }^{3}$, Angela Nebbioso ${ }^{3}$, \\ Francesca Garofalo ${ }^{1}$, Lucia Altucci ${ }^{3}$, Federica Corrado ${ }^{1}$ \\ ${ }^{1}$ Istituto Zooprofilattico Sperimentale del Mezzogiorno di Portici (NA), Naples, Italy; ${ }^{2}$ Pathology Center of the \\ Cornea and Ocular Surface-U.O. of Ophthalmology P.O. San Giovanni Bosco, Naples, Italy; ${ }^{3}$ Department of \\ Medicine of Precision, University of Studi della Campania Luigi Vanvitelli, Naples, Italy \\ Correspondence to: Federica Corrado, federica.corrado@cert.izsmportici.it
}

Keywords: Ozonated Oil in Liposomes, Staphylococcus aureus, Pseudomonas aeruginosa, Cytotoxicity, MTT Assay Received: May 29, 2019 Accepted: July 5, $2019 \quad$ Published: July 8, 2019

Copyright $\odot 2019$ by author(s) and Scientific Research Publishing Inc.

This work is licensed under the Creative Commons Attribution-NonCommercial International License (CC BY-NC 4.0).

http://creativecommons.org/licenses/by-nc/4.0/

\section{(c) (1) \& Open Access}

\section{ABSTRACT}

Effect of the ozonated oil in liposomes: they act against Staphylococcus aureus and Pseudomonas aeruginosa is among the most frequent eye pathogens and causes acute and chronic infections of the ocular surface. Staphylococcus aureus and Pseudomonas aeruginosa were tested in this study. The bacterial suspension of Staphylococcus aureus was diluted to obtain $150 \mathrm{CFU} / \mathrm{ml}$. The bacterial suspension of Pseudomonas aeruginosa was diluted to obtain $15 \mathrm{CFU} / \mathrm{ml}$. Various volumes of liposome-vehiculated ozonated oil were added $(400 \mu \mathrm{l}, 200 \mu \mathrm{l}, 100 \mu \mathrm{l}$ and $50 \mu \mathrm{l})$ to $100 \mu \mathrm{l}$ of bacterial suspension; both of Staphylococcus aureus and Pseudomonas aeruginosa are incubated at $37^{\circ} \mathrm{C}$ for 10 minutes. The cytotoxicity of liposome-vehiculated ozonated oil was analysed at the University of Campania "Luigi Vanvitelli", Department of Precision Medicine. The HaCaT epidermal keratinocyte cell line (ATCC, USA) was grown in Dulbecco's Modified Eagle Medium (Euroclone) with the addition of $10 \%$ foetal bovine serum (FBS) (Euroclone), $2 \mathrm{mM}$ of L-glutamine (Euroclone) and antibiotics (100 U/ml penicillin, $100 \mathrm{~g} / \mathrm{ml}$ streptomycin) (Euroclone). The microbiological results clearly show the antimicrobial efficacy of liposome-vehiculated ozonated oil against bacterial strains such as Staphylococcus aureus and Pseudomonas aeruginosa. Furthermore, the studies carried out in vitro on the keratinocyte line showed how ozonated oil in liposomes does not evidence any cell toxicity, and that after 3 days of treatment, it promotes cell growth compared to the positive control.

\section{INTRODUCTION}

The increase of antibiotic resistance is an actual emergency in general medicine and in ophthalmolo- 
gy [1]. Identifying new molecules capable of performing an effective antibacterial action, which do not cause antibiotic resistance and are well tolerated by ocular tissues can be a turning point in the ophthalmologist's therapeutic choices. Oxidising agents are commonly used for their ability to effectively disinfect both the skin and solid surfaces. However, their introduction in the form of eye drops for disinfection of the ocular surface is very recent. Their use essentially offers two advantages: they act against all microorganisms and do not induce antibiotic resistance. Ozone, the most powerful oxidising agent found in nature, has been used in medicine for over a century in the form of $\mathrm{O}_{3}$ gas owing to its antiseptic and anti-inflammatory properties [2].

"Ozone is a powerful antibacterial, antiviral and antifungal agent. It may represent the future of the fight against infections".

However, gaseous ozone, as such, is highly unstable, but can be stabilised as ozonide, an organic form obtained by having gaseous ozone which reacts with the double bonds of the carbon atoms of plant oils: the derived ozonated oil retains the properties of ozone. To make it tolerated by the ocular surface, a nanoemulsion with ozonated oil within liposomes in solution with hypromellose and deionised water has been recently placed on the market in the form of eye drops [3, 4].

Staphylococcus aureus is among the most frequent eye pathogens and causes acute and chronic infections of the ocular surface. In recent years, its ability to withstand common antibiotic therapies has significantly increased, mainly owing to misuse of these therapies [5,6].

Pseudomonas aeruginosa is a redoubtable opportunistic pathogen that, especially in contact lens wearers, may infect the cornea causing severe corneal ulcers [7].

It is hard to eradicate due to its high ability to resist antibiotic therapies [8].

For about one year now we have been using this ophthalmic solution based on ozonated oil in microbial ocular surface diseases-either alone or in combination with traditional therapy-at the Cornea and Ocular Surface Pathology Centre of the San Giovanni Bosco Hospital of Naples with satisfactory clinical results.

The purpose of this study was to prove unequivocally that a solution of ozonated oil in liposomes applied to the ocular surface had antimicrobial properties and did not cause any damage. As a matter of fact, one must take into account that a solution of ozonated oil in liposomes appears opalescent; hence it was not possible to read turbidity, an "indicator of bacterial growth", with the conventional and well-established techniques for serial dilutions [9].

An ad hoc method therefore needed to be identified that would comply with all scientific criteria. This method was indeed tested on Staphylococcus aureus and Pseudomonas aeruginosa.

Specifically, in this study we tested the antiseptic ability of liposome-vehiculated ozone against these two bacteria, its non-toxicity and its possible epithelium restoring action.

\section{MATERIALS AND METHODS}

\subsection{Bacterial Strains}

Bacterial strains used in this study were Staphylococcus aureus ATCC25923 and Pseudomonas aeruginosa ATCC27853, both from clinical sample, supplied from the internal laboratory of the Istituto Zooprofilattico Sperimentale del Mezzogiorno. The bacterial strains were diluted with saline to reach a concentration of $150 \times 10^{6} \mathrm{CFU} / \mathrm{ml}$. The turbidity of the suspension was measured with a $600 \mathrm{~nm}$ densitometer (Lambda-25 spectrophotometer, Perkin-Elmer, USA) according to the Mc Farland 0.5 standard. The bacterial suspension was diluted to the concentration of $15 \times 10^{-9} \mathrm{CFU} / \mathrm{ml}$.

Various volumes of liposome-vehiculated ozonated oil were added (400 $\mu \mathrm{l}, 200 \mu \mathrm{l}, 100 \mu \mathrm{l}$ and $50 \mu \mathrm{l})$ to $100 \mu \mathrm{l}$ of bacterial suspension, both of Staphylococcus aureus and Pseudomonas aeruginosa and incubated at $37^{\circ} \mathrm{C}$ for 10 minutes. This time was chosen to simulate as closely as possible the conditions that occur after applying one drop only in one eye.

After that, $100 \mu \mathrm{l}$ of the four solutions thus prepared (inoculum A, inoculum B, inoculum C and inoculum D), were seeded on blood Agar plates for Staphylococcus aureus and Agar nutrient for Pseudo- 
monas aeruginosa. Furthermore, for each bacterial strain, a positive control (only Staphylococcus aureus and only Pseudomonas aeruginosa) and a negative control only consisting of liposome-vehiculated ozonated oil were added, in order to rule out any contamination. The Staphylococcus aureus plates were then incubated overnight at $37^{\circ} \mathrm{C}$. While the Pseudomonas aeruginosa ones were incubated at $25^{\circ} \mathrm{C}$ for 48 hours.

\subsection{Cell Culture}

The cytotoxicity of liposome-vehiculated ozonated oil was analysed at the University of Campania "Luigi Vanvitelli", Department of Precision Medicine.

The HaCaT epidermal keratinocyte cell line (ATCC, USA) was grown in Dulbecco's Modified Eagle Medium (Euroclone) with the addition of $10 \%$ foetal bovine serum (FBS) (Euroclone), $2 \mathrm{mM}$ of L-glutamine (Euroclone) and antibiotics (100 U/ml penicillin, $100 \mathrm{~g} / \mathrm{ml}$ streptomycin) (Euroclone).

\subsection{MTT Assay}

The MTT assay [3-(4,5-dimethylthiazol)-2,5-diphenyl-tetrazolium bromide] [10] (Sigma) was used to establish cell viability after treatment with the eye drops. The HaCaT were plated at a confluence of $6 \times 10^{4}$ cells per point, in 24-well plates, and treated, in triplicate, with three different amounts of the ozonated oil solution in liposomes at different concentrations $(50 \mu \mathrm{l}, 100 \mu \mathrm{l}$ and $200 \mu \mathrm{l})$ three times a day for 3 days. The treatment with the eye drops was performed for $10 \mathrm{~min}$, after which the pharmaceutical product was removed from the plate and the cells were incubated again with fresh medium.

After 72 hours of treatment, the MTT solution was added at a concentration of $0.5 \mathrm{mg} / \mathrm{ml}$, and incubated for 3 hours at $37^{\circ} \mathrm{C}$. The formazan crystals were finally solubilised in DMSO (Sigma) and absorbance was read with TECAN M-200 at a wavelength of $570 \mathrm{~nm}$.

\subsection{Cell Count}

The cells were counted with a $0.5 \%$ trypan blue solution in a Burker chamber.

\subsection{Image Capture}

The cell images were captured with Cytation ${ }^{\mathrm{TM}} 5$ Cell Imaging Multi-Mode Reader (BioTeK).

\section{RESULTS}

\subsection{Anti-Microbial Activity}

The bactericide activity for Staphylococcus aureus at the bacterial concentration of $150 \mathrm{CFU} / \mathrm{ml}$ was $80 \%$ with $400 \mu \mathrm{l}$ of liposome-vehiculated ozonated oil, $76 \%$ with $200 \mu \mathrm{l}$ of liposome-vehiculated ozonated oil, $54 \%$ with $100 \mu \mathrm{l}$ of liposome-vehiculated ozonated oil, $46 \%$ with $50 \mu \mathrm{l}$ of liposome-vehiculated ozonated oil (Figure 1(a), Figure 1(b) and Figure 2). The bactericide action against Pseudomonas aeruginosa was lower. Indeed no bactericide activity was highlighted at the bacterial concentration of $150 \mathrm{CFU} / \mathrm{ml}$ but at the concentration of $15 \mathrm{CFU} / \mathrm{ml}$. The bactericide activity for Pseudomonas aeruginosa was $60 \%$ with $400 \mu \mathrm{l}$ of liposome-vehiculated ozonated oil, $46 \%$ with $200 \mu \mathrm{l}$ of liposome-vehiculated ozonated oil, $28 \%$ with $100 \mu \mathrm{l}$ of liposome-vehiculated ozonated oil, with $50 \mu \mathrm{l}$ of liposome-vehiculated ozonated oil growth exceeded $400 \mathrm{CFU}(\sim 1 \%)$ (Figures 3(a)-(c) and Figure 4).

\subsection{Toxicity Assessment}

In order to assess the toxicity of ozonated oil in liposomes, the ophthalmic solution was tested on normal epithelial keratinocyte cells, HaCaT. The cell viability test by means of MTT assay [10] made it possible to observe that ozonated oil in liposomes does not inhibit cell growth at all, as shown in Figure 5(a). On the contrary, a quantitative assessment, obtained by cell count, shows how $100 \mu \mathrm{l}$ and $200 \mu \mathrm{l}$ of 
(a)

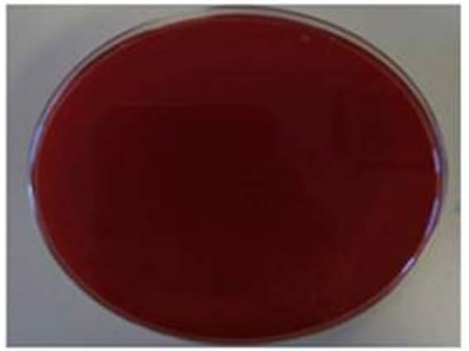

(b)

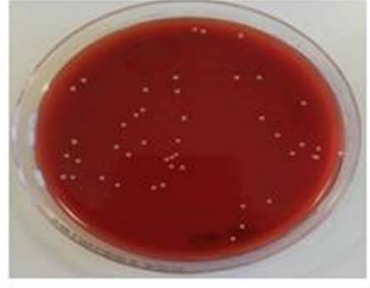

IA
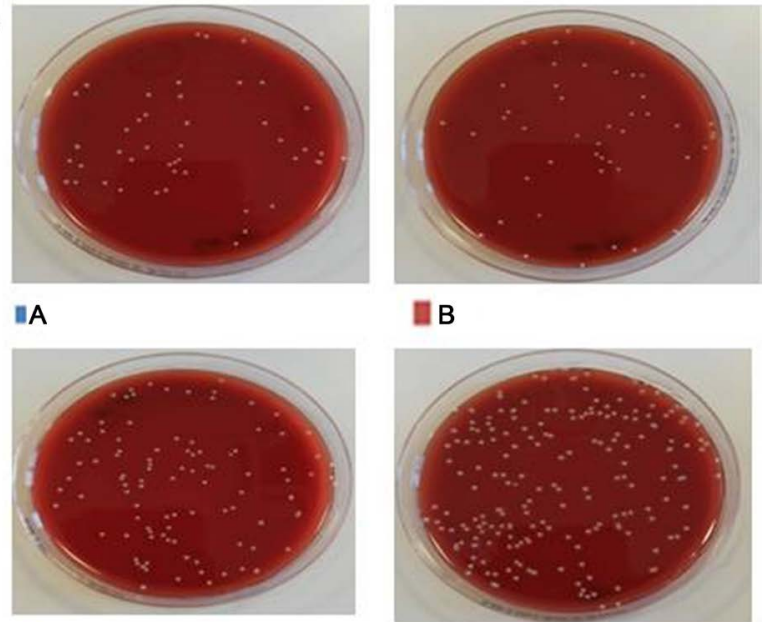

$\| \mathrm{C}$

11 $\mathrm{B}$

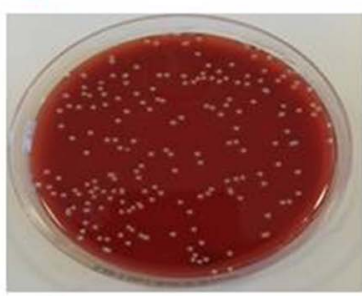

I $\mathrm{D}$

Figure 1. Staphylococcus aureus ATCC25923 positive control. (a) Negative control; (b) Effect of ozonated oil in liposomes on Staphylococcus aureus ATCC25923. Panel A is Inoculum A (bactericide activity for $S$. aureus was $80 \%$ ). Panel B is Inoculum B (bactericide activity for $S$. aureus was 76\%). Panel C is Inoculum C (bactericide activity for $S$. aureus was $54 \%$ ). Panel D is Inoculum D (bactericide activity for $S$. aureus was $46 \%$ ).

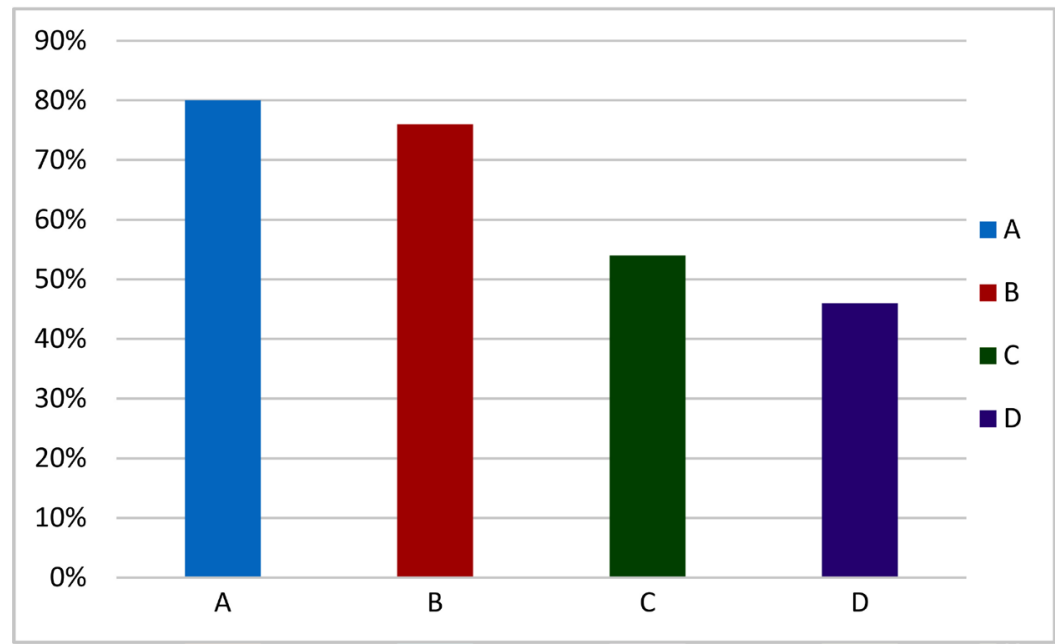

Figure 2. Bactericide action of ozonated oil in liposomes on Staphylococcus aureus ATCC25923. Inoculum A (bactericide activity for $S$. aureus was $80 \%$ ). Inoculum B (bactericide activity for $S$. aureus was $76 \%$ ). Inoculum C (bactericide activity for $S$. aureus was $54 \%$ ). Inoculum D (bactericide activity for $S$. aureus was $46 \%$ ). 


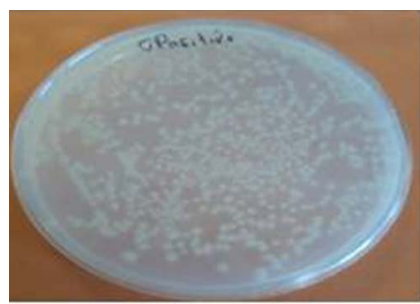

(a)

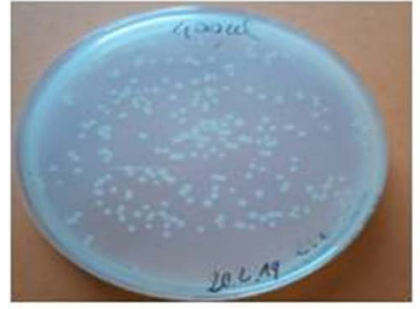

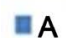

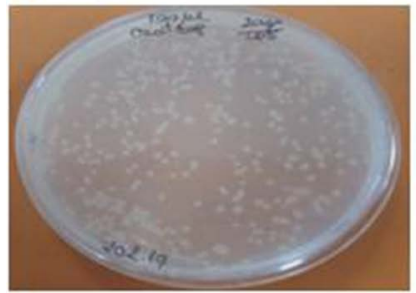

플 $\mathrm{C}$

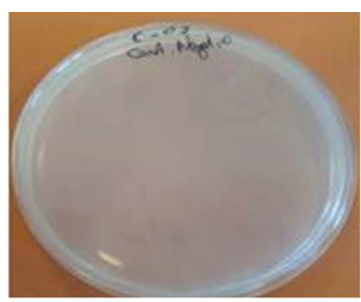

(b)

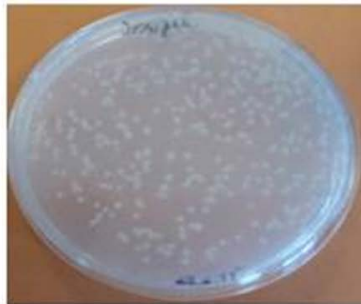

II

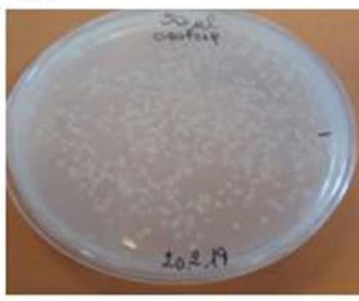

(c)

Figure 3. (a) Pseudomonas aeruginosa ATCC27853 positive control; (b) Negative control; (c) Effect of ozonated oil in liposomes on Pseudomonas aeruginosa ATCC27853. Panel A is Inoculum A (bactericide activity for $P$. aeruginosa was $60 \%$ ). Panel B is Inoculum B (bactericide activity for $P$. aeruginosa was $46 \%$ ). Panel $\mathrm{C}$ is Inoculum $\mathrm{C}$ (bactericide activity for $P$. aeruginosa was $28 \%$ ). Panel D is Inoculum $\mathrm{D}$ (bactericide activity for $P$. aeruginosa was $\sim 1 \%$ ).

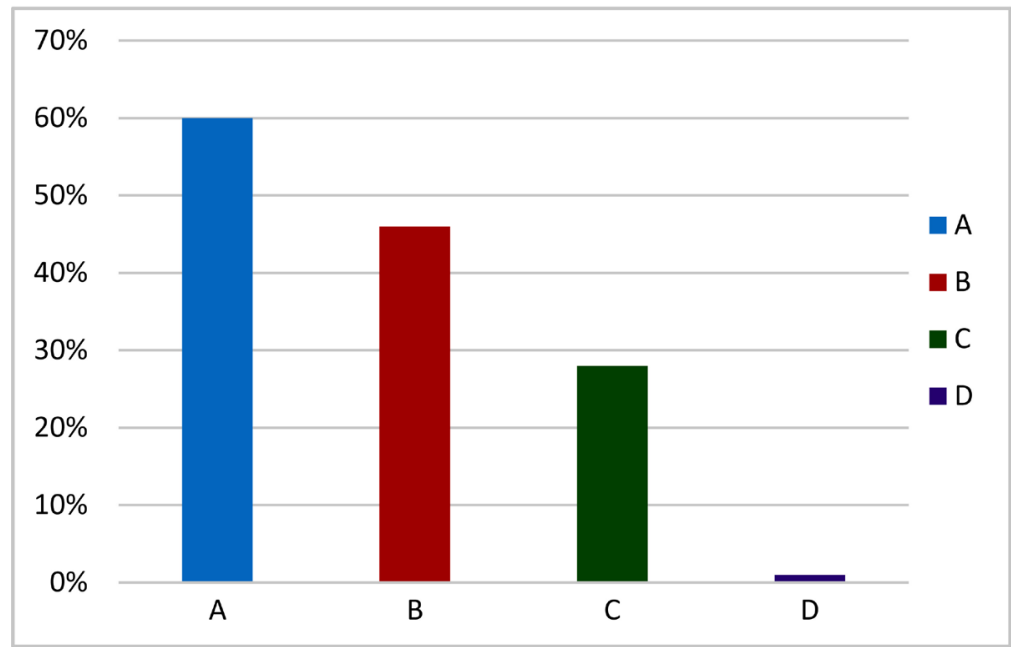

Figure 4. Bactericide action of liposome-vehiculated ozonated oil on Pseudomonas aeruginosa ATCC27853. Inoculum A (bactericide activity for $P$. aeruginosa was $60 \%$ ). Inoculum B (bactericide activity for $P$. aeruginosa was $46 \%$ ). Inoculum C (bactericide activity for $P$. aeruginosa was $28 \%$ ). Inoculum D (bactericide activity for $P$. aeruginosa was $\sim 1 \%$ ). 

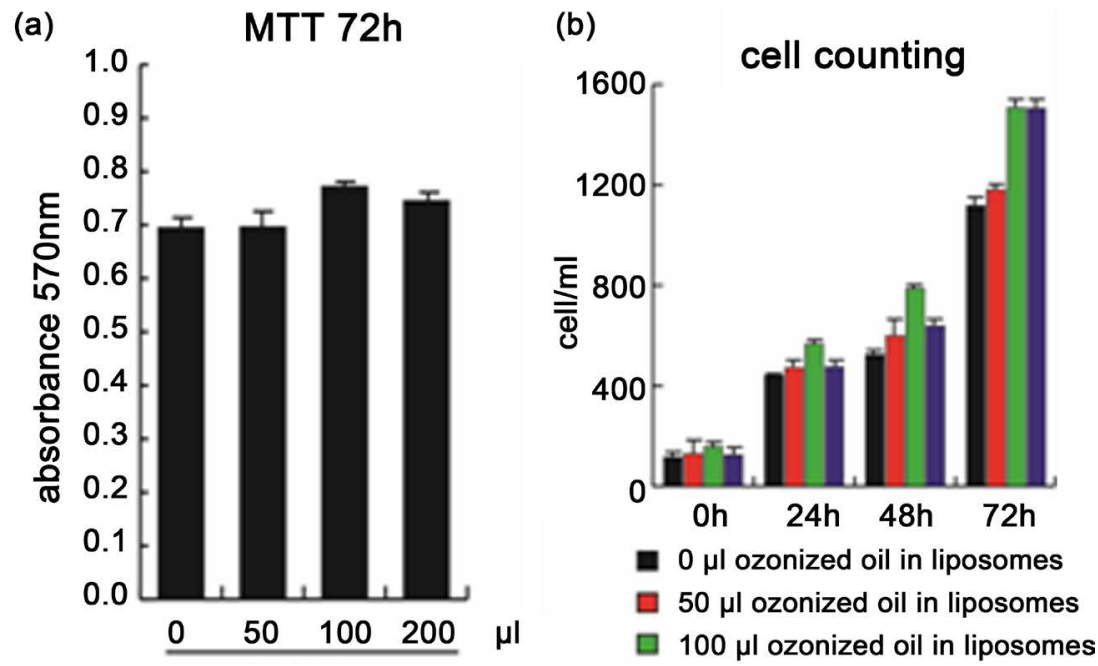

(c)

Ozonated oil in liposomes

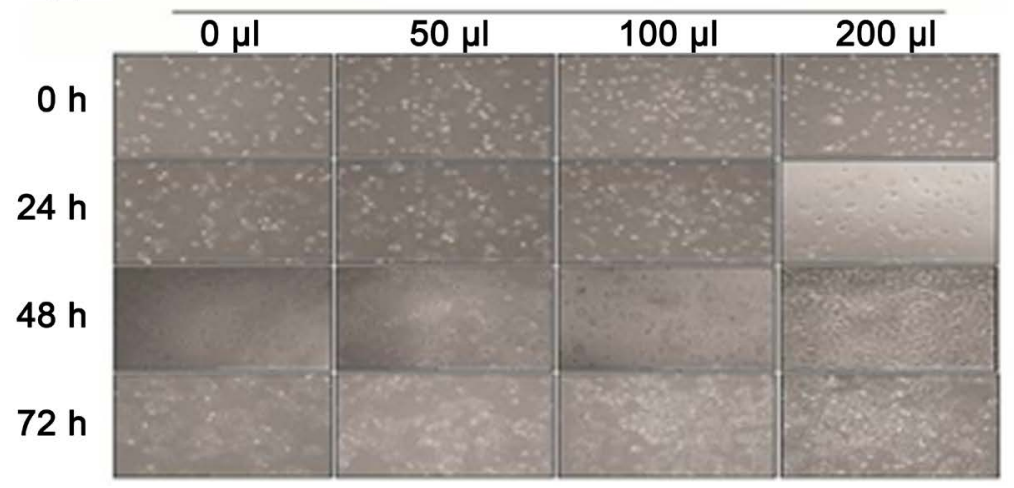

Figure 5. (a) MTT assay on HaCaT keratinocyte cells after 72 hours of treatment; (b) Cell count on $\mathrm{HaCaT}$ keratinocyte cells; (c) $\mathrm{HaCaT}$ imaging (Cytation ${ }^{\mathrm{TM}}$ Cell Imaging Multi-Mode Reader) after treatment with ozonated oil in liposomes. Black bar scale: $1000 \mu \mathrm{m} .4 \times$ magnification.

ozonated oil solution in liposomes is able to promote cell growth after 72 hours of treatment compared to the control (Figure 5(b)). The data are supported by visual analysis via Cytation ${ }^{\mathrm{TM}} 5$ Cell Imaging Multi-Mode Reader (BioTeK) (Figure 5(c)).

\section{DISCUSSION}

The microbiological results clearly show the antimicrobial efficacy of liposome-vehiculated ozonated oil against bacterial strains such as Staphylococcus aureus and Pseudomonas aeruginosa.

Furthermore, the studies carried out in vitro on the keratinocyte line showed how ozonated oil in liposomes does not evidence any cell toxicity, and that after 3 days of treatment, it promotes cell growth compared to the positive control.

The results obtained support the evidence already provided by clinical experience-with administration of one eye drop four times a day-confirming both the tolerability of the solution and its effectiveness either on its own or in combination with conventional therapy in the treatment and prevention of microbial diseases of the ocular surface.

\section{ACKNOWLEDGEMENTS}

This study stems from the collaboration of three work groups to demonstrate the bacterial efficacy of 
ozonated oil solution in liposomes and not cell toxicity.

\section{CONFLICTS OF INTEREST}

The authors declare no conflicts of interest regarding the publication of this paper.

\section{REFERENCES}

1. Asbell, P.A. and DeCory, H.H. (2018) Antibiotic Resistance among Bacterial Conjunctival Pathogens Collected in the Antibiotic Resistance Monitoring in Ocular Microorganisms (ARMOR) Surveillance Study. PLoS ONE, 13, e0205814. https://doi.org/10.1371/journal.pone.0205814

2. Travagli, V., Zanardi, I. and Bocci, V. (2009) Topical Applications of Ozone and Ozonated Oils as Anti-Infective Agents: An Insight into the Patent Claims. Recent Patents on Anti-Infective Drug Discovery, 4, 130-142. https://doi.org/10.2174/157489109788490271

3. Lamberto, R., Mawsouf, M.N., Menéndez, S., Olga, S., León Sánchez, G.M. and Hernández, F. (2008) Ozone Therapy: Clinical and Basic Evidence of Its Therapeutic Potential. Archives of Medical Research, 39, 17-26. https://doi.org/10.1016/j.arcmed.2007.07.005

4. Spadea, L., Tonti, E., Spaterna, A. and Marchegiani, A. (2018) Use of Ozone-Based Eye Drops: A Series of Cases in Veterinary and Human Spontaneous Ocular Pathologies. Case Reports in Ophthalmology, 9, 287-298. https://doi.org/10.1159/000488846

5. Jang, H.J., Chung, I.Y., Lim, C., Chung, S., Kim, B.O., Kim, E.S., Kim, S.H. and Cho, Y.H. (2019) Redirecting an Anticancer to an Antibacterial Hit against Methicillin-Resistant Staphylococcus aureus. Frontiers in Microbiology, 10, 350. https://doi.org/10.3389/fmicb.2019.00350

6. Subedi, D., Vijay, A.K., Kohli, G.S., Rice, S.A. and Willcox, M. (2018) Association between Possession of ExoU and Antibiotic Resistance in Pseudomonas aeruginosa. PLoS ONE, 13, e0204936. https://doi.org/10.1371/journal.pone.0204936

7. Rağbetli, C., et al. (2016) Evaluation of Antimicrobial Resistance in Staphylococcus aureus Isolates by Years. Interdisciplinary Perspectives on Infectious Diseases, 2016, Article ID: 9171395. https://doi.org/10.1155/2016/9171395

8. Tang, A., Caballero, A.R., Marquart, M.E. and O'Callaghan, R.J. (2013) Pseudomonas aeruginosa Small Protease (PASP), a Keratitis Virulence Factor. Investigative Ophthalmology \& Visual Science, 54, 2821-2828. https://doi.org/10.1167/iovs.13-11788

9. Clinical and Laboratory Standards Institute (CLSI) (2015) Performance Standards for Antimicrobial Disk and Dilution Susceptibility Tests for Bacteria Isolated from Animals. Document VET 01S-Ed. 3.

10. Stockert, J.C., Blázquez-Castro, A., Cañete, M., Horobin, R.W. and Villanueva, A. (2012) MTT Assay for Cell Viability: Intracellular Localization of the Formazan Product Is in Lipid Droplets. Acta Histochemica, 114, 785-796. https://doi.org/10.1016/j.acthis.2012.01.006 